\title{
Reflections on methodology for assessing campus sustainability from a Turkish perspective
}

\author{
Author: Serhat Basak
}

\begin{abstract}
Aim: The author provides a critical reflection of the questionnaire discussed at the workshop "Methodology for assessing the campus sustainability from the perspective of multi-level antifragility" held on Friday 13 May at the WSB University in Wrocław. The author reflects from the background of his experience in Turkey.

Design / Research methods: The author provides his own reflections and opinions, based on the discussions at the workshop.

Conclusions / findings: It is very difficult to create a set of indicators making campus sustainability internationally comparable, as well as finding proper sources of information. A starting point in creating such indicators may be mistakes threatening organizational viability and sustainability of the external environment.

Originality / value of the article: The article provides critical feedback on an innovative approach towards research on campus sustainability.
\end{abstract}

Keywords: campus sustainability, sustainability management, fragility, antifragility, methodology

JEL: Q01, B40, 123

\section{Introduction}

The participation in the workshop on Campus sustainability was an experience, because when doing my studies in "Graphical Design - American Culture and Literature - International Relations" of Bilkent University (Turkey $)^{1}$ I had not been in touch with

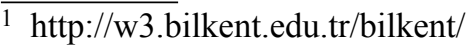

History: received 2016-11-25, corrected 2016-11-27, accepted 2016-11-27

this subject. My first reaction was that the individual campus in itself cannot contribute much to sustainability. However, in the discussion of the questionnaire the idea that it may be more important to prevent contribution to unsustainable development than to contribute to sustainability became an idea I started to appreciate. Furthermore, small efforts can make a large difference. 
My home university, Bilkent University, is a private university in Ankara in Turkey. From the website, it can be inferred that the university is doing efforts to contribute to sustainability. It uses solar power, has its own paper factory using recycled paper, reuses waste, uses water filters in order to make tap water more attractive and reduce the consumption of bottled water, etc. However, as the number of students is about 35,000 , of whom about $70 \%$ live in student dormitories $^{2}$, the accumulated effects may be significant. In this context, the survey discussed at the workshop is relevant as it seems to focus of the capacity of the university to contribute to sustainability, or at least to prevent unsustainable actions. In this short paper I present some of my ideas and doubts about the approach in the research.

\section{Reflections}

An important element of the survey seems to be the importance of the educational process for sustainability. This is as such a complex issue, as educational staff members have their own ideology regarding teaching, and different expectations regarding to students. This creates a serious challenge in establishing a proper sample of the whole university. There are so many teachers, while students only have classes with a small part of them. For this reason, the assessment by students only counts for the impression they have based on their own experience. Furthermore, I have the impression that many students are only interested in good grades and a diploma. While this as such already questions the willingness to obtain knowledge and think critically, it also makes assessment of the educational situation of the university

\footnotetext{
2 http://www.bilkent.edu.tr/bilkent-tr/ admin-unit/yurt/e_yurt.htm
}

more difficult. Even when lecturers would try to support knowledge creation and critical thinking, the group of students aiming at obtaining a diploma may not be interested in this. In this case, it is questionable whether these students are a reliable source of information. What in this context is missing in the questionnaire is a question regarding the motivation of a student to study.

Besides the mentioned issue, whether a university is private, public and/ or religious can radically change answers. It may be that the religious background, combined with experience and personal expectations, changes the perception of reality. For example, concerning discussion and asking questions during class, for one person, one question per class may be a lot, while for the other this may be very little. The diversity in background is not clear in the survey. Like religion, political background can be important in explaining sustainability efforts as well as the power to destroy all the dignity of the university. Interest groups and political influence are important for university viability. Bilkent University is probably not unique in its development path. The core of its development strategy was influenced by, among others, the engineering, science and chemistry departments, at the expense of literature, history, art and other studies. This in order to become an internationally recognized university, and to be attractive for students who can combine different studies and advance in different types of science. A question is whether such a developmental path will not lead to overemphasis on science and engineering and related specific knowledge. The rector, coming from a science department, thinks that "mankind is only evolving with the help of science." and "putting university sources to science departments will lead Bilkent 
to higher ranks ${ }^{3 \prime}$ was his election slogan. Too much focus on one path of development may close options for different types of studies creating different kinds of knowledge, closing the way for new ideas regarding campus sustainability.

Regarding the questions on governance issues, it is doubtful whether many staff members of students can really answer these questions, as this requires specific knowledge. For example, students will have great difficulties to assess whether firing half of the staff will be a good idea. There may be hundreds of teachers, while students only have classes with a small part of them. As such, the answer will be likely "don't know" or an opinion based on own experience with a few teachers. Furthermore, firing staff members may lead a chaotic environment because there will be for sure some people who are really good but need to be fired because they do not fit the tests or a certain norm that is standardized by a formula. Maybe students would like to see some of the professors out of

\footnotetext{
$3 \mathrm{https}: / / \mathrm{w} w w . t i m e s h i g h e r e d u c a t i o n$. com/world-university-rankings/bilkent-university\#ranking-dataset/589595
}

the department but still dry wood will be able to burn the wet wood too.

\section{Concluding remarks}

It will be a real challenge to create a set of indicators making universities internationally comparable regarding campus sustainability. Many issues depend on differences in the type of university, the economic situation, legal rules, culture, etc. In order to catch all these issues, a multiple of indicators may be required as, for example, IT is very important in computer science, but literature studies can function very well without it. Added to this, it will be difficult to find a reliable source of information. A good starting point for comparability may be mistakes. They make universities comparable as they are important in the process of creating knowledge. This will be a challenge, as there may be different cultural perceptions on what are mistakes. However, in particular the mistakes that threaten university viability and/or sustainability of the external environment can be a starting point. The reason is that they are a clear threat to the university's functioning and survival, as well as to sustainable development.

\title{
Uwagi o metodologii szacowania zrównoważonego rozwoju kampusu z perspektywy tureckiej
}

\begin{abstract}
Abstrakt
Cel: Autor pokazuje krytyczną refleksję na temat kwestionariusza warsztatów „Metodologia oceny zrównoważonego rozwoju kampusu z perspektywy antykruchości wielopoziomowej", które zostały zorganizowane przez Wyższą Szkołę Bankową we Wrocławiu 13 maja 2016 r. Uwagi autora wywodzą się z jego doświadczenia w Turcji.

Metoda badawcza: Autor przekazuje swoje uwagi i opinie w oparciu o dyskusję przeprowadzoną podczas warsztatów.

Wnioski: Bardzo trudno jest opracować zespół wskaźników zrównoważonego rozwoju kampusu o charakterze porównawczym w kontekście międzynarodowym, jak również wskazać na właściwe źródła informacji. Punktem wyjścia dla określenia takich wskaźników mogą być błędy zagrażające żywotności organizacyjnej i zrównoważony rozwój otoczenia zewnętrznego.
\end{abstract}


Oryginalność / wartość artykułu, wkład w rozwoju nauki: Artykuł zawiera krytyczną informację zwrotną na temat innowacyjnego podejścia do badania zrównoważonego rozwoju kampusu.

Słowa kluczowe: zrównoważony rozwój kampusu, zarządzanie zrównoważonego rozwoju, kruchość, antykruchość, metodologia 